\title{
AYURLOG
}

National Journal of Research in Ayurved Science

http://www.ayurlog.com $\quad$ April- June: 2021|Volume: 09th $\mid$ Issue: $2^{\text {nd }}$

ISSN: $2320-7329$

\section{Literature Review of Swapna \& Swapnavishayak Arishta of Charak Indriya Sthana \& its significance in prognosis of disease.}

\author{
Saurabh Ravindra Shirishkar*1, Ganesh S. Puradkar², Sujay Randive
}

1. PG Scholar, Samhita \& Siddhant Department, Ayurved Mahavidyalaya, Sion, Mumbai, Maharashtra.

2. Associate Professor, Samhita \& Siddhant Department, Ayurved Mahavidyalaya, Sion, Mumbai, Maharashtra.

3. Reader, Department Of Samhita, Bhagwant Ayurvedic College \& Bhagwant Hospital, Muzaffarnagar (U.P.)

*Corresponding author: shirishkarsaurabh@gmail.com

\section{Abstract:}

Ayurved, a science which is constant and everlasting. It maintained its domain in the medical sciences. It deals all parts of life, based on its fundamental principles. Charak samhita is the most conclusive and complete concise edition of Ayurvedic literature. Indriya sthana deals with various fatal signs and symptoms which denote imminent death and knowledge of life expectancy in the patients who are at end-of-life stages. Indriya sthana of Charak samhita comprises 12 chapters and 'Purvarupeeyam indriyam' is the $5^{\text {th }}$ chapter of Indriya sthana. 'Purvarupeeyam indriyam' section gives the ideas like physiology and classification of swapna (dreams), auspicious and foreboding dreams, and arishta lakshanas relating to dreams.
Now a day, Swapna phenomenon isn't in clinical practice that much but it has its own significance in the field of medicine.

Keywords: Swapna, Arishta, Ayurved.

\section{INTRODUCTION}

\section{Charak Samhita is Chikitsa}

Grantha. The Indriya sthana of Charak Samhita is its remarkable element. Chakrapani expressed 'Indra' signifies 'Prana' and signs showing its end are known as 'Indriya' (1). The part of Charak Samhita which contains information about Indriya is named as 'Indriya Sthana'. Swapna (Dreams) are likewise one of the elements of the human body in both the physiological condition and pathological condition.

Swapna (dreams) is a key to understand the mind, to analyze a disease, to 
survey the prognosis of a condition, for character assessment and furthermore to know life expectancy. The swapna (dream) has been portrayed from physiological, pathological, diagnostic, prognostic and remedial perspective in Ayurvedic literature. Additionally it signifies the disease condition, Arishta. Sometimes the Lakshanas of the disease don't appear to be very particular; at such critical points in time, predominance in the Swapna or the kind of Swapna may prompt the finding. However, now a day Swapna isn't in clinical practice as referred above. All the old Ayurvedic researchers have given extraordinary significance to this idea directly from birth to death in various aspects.

\section{AIM \& OBJECTIVES}

A) To review literature of Swapna as mentioned in Charak Indriya sthana.

B) To review Swapnavishayak Arishta $\&$ its significance in prognosis of disease as mentioned in Charak Indriya sthana.

\section{REVIEW OF LITERATURE}

\section{A] Swapna -}

When the Manovahasrotus (mind related system) are saturated by the excessively vitiated by three doshas, such dreadful dreams appear in sleep. Here Acharya has considered that Manovahasrotus has connecting channels all over the body as specially Mana is located at
Hriday so Dasha Dhamani of Hriday are Manovahasrotus only ${ }^{(2)}$.

The person who is not in deep sleep (Naatiprasupta Avastha), sees various fruitful i.e. Safal or fruitless i.e. Nishfal dreams in association with sense organs ${ }^{(3)}$.

Acharya Charak has mentioned seven types of Swapna which are 1) Drishta 2) Shruta 3) Anubhuta 4) Prarthita 5) Kalpita 6) Bhavika \& 7) Doshaja

1) Drishta - Which is seen in awaken condition.

2) Shruta - Which we have heard.

3) Anubhuta - Which we have experienced by our sense organs (except eyes $\&$ ears).

4) Prarthita - Which we have wished to happen.

5) Kalpita - Which we have imagined.

6) Bhavika - Which gives good or bad signs of future.

7) Doshaja - Which appears due to Vaatadi dosha.

Classification of above mentioned types into Safal (fruitful) \& Nishfal (fruitless) Swapna:

Out of seven types of Swapna first five types (1.Drishta 2.Shruta 3.Anubhuta 4.Prarthita 5.Kalpita) are Nishfal Swapna. Similarly which dream appears in daytime is Nishfal \& which dream is too short or too long are Nishfal (irrespective of daytime or night time) ${ }^{(4)}$. 
Remaining two (Bhavika \& Doshaja) are Safal dreams which give good or bad effects. Doshaja Swapna is due to vitiated Doshaja Avastha which is fruitful in disease condition.

Dreams which appears in the first part of night are Alpa fal (partially fruitful) $\&$ the dream which appears in last part of the night $\&$ after that if person doesn't sleep then that Swapna (dream) is strongly fruitful. Acharya Charak stated that if a person have seen an inauspicious dream \& again sees without waking up another dream that is auspicious and beneficial then the person meets with good results ${ }^{(5)}$.

The physician who understands premonitory symptoms which are associated with such dreadful dreams never starts the treatment for incurable diseases ${ }^{(6)}$.

\section{B] Swapna Vishayak Arishta (Prognosis Based on Dreams) -}

The person who sees dreadful dreams in some diseases it indicates death of a person. Even if a person is healthy \& sees such horrible dreams then his life becomes doubtful, rarely does person escape.

\section{a) Bad Prognostic Dreams in} Rajayakshma -

A person who in dreams, travelled by dog, camel or a donkey towards south direction, leaves his life. A person who in his dreams takes alcohol with demons and who is dragged by a dog leaves his life getting affected with severe fever ${ }^{(7)}$.

b) Bad Prognostic Dreams in Raktapitta -
A person who sees sky nearby which is dyed with red colour like red lac leaves his life due to affected with severe bleeding disorder. A person in his dream sees himself adorned with red garlands, clad with red clothes, anointed with red dye, continuously laughing \& dragged by woman to somewhere will result into death due to severe bleeding disorders ${ }^{(8)}$.

\section{c) Bad Prognostic Dreams in Gulma -}

A person, who in his dreams sees hard and thorny creepers grown in his heart then person gets affected by Gulma, which leads to death of a person ${ }^{(9)}$.

\section{d) Bad Prognostic Dreams in Kushtha -}

A person who in his dream sees himself naked, anointed with ghee, doing the havan (ritual burning offerings) without the fire being lit \& during it who has lotuses grown on his chest, will result into death of a person due to skin diseases ${ }^{(10)}$.

\section{e) Bad Prognostic Dreams in Prameha -}

A person who sees in his dreams, drinking various kinds of Snehas (oily substances) with Chandalas becomes affected by Prameha and will lead to death $^{(11)}$.

\section{f) Bad Prognostic Dreams in Unmad -}

The man who in his dreams dances with evil spirits and sinks in water leaves the world due to epilepsy ${ }^{(12)}$.

\section{g) Bad Prognostic Dreams in Apasmar -}

A person who sees in dreams he dancing with ghosts \& dragged by ghost 
with his head upside down, will lead to death due to affected with epilepsy ${ }^{(13)}$.

\section{h) Bad Prognostic Dreams in Bahirayama}

A person in his dream sees him taking cakes of sesame seeds and apupa ( a dietary item) and vomits the similar when he is awake, leads to death due to Bahirayama ${ }^{(14)}$.

\section{General Bad Prognostic Dreams -}

Certain other dreadful dreams which should also be analyzed as they indicate the result as death of the disease or a healthy person.

A person who in his dreams sees bamboos, shrubs and creepers etc. growing in his head, birds coming to them and his scalp been shaved or who in his dreams sees himself surrounded by vultures, owls, dogs, crows and other birds or by Rakshasa, dead men, Pishachas, women, Chandalas, and residents of Dravida and Andhra regions.

An individual who in his dreams ends up encompassed by pathless backwoods of bamboo, sticks, creepers, grass and thorny plants and tumbles down while attempting to come out.

An individual who in his dreams, tumbles down on the exposed ground covered with dust or upon an ant colony dwelling place or upon cinders, or upon a crematorium or in to hole.

An individual who sinks in a dump or lake of messy water or into soil or in a dull well or who is diverted by a quick flow Or then again who in his dreams drinks slick substances or blesses his body with oil, vomits, defecates, or gets gold, takes part in squabble, gets defeated and caught.

Or then again who lose his shoes, has skin of feet stripping off or feels energized or who is reprimanded by his angry progenitors or who finds in his dreams the fall or demolition of his own tooth or the moon or the sun or the stars or the consuming lights or his own eyes or the breaking of a mountain.

Or on the other hand who in his dreams, enters a forest with red blossoms or where sinful activities are done or crematorium, a dim cavern.

Or on the other hand who in his dreams sees himself continuing towards south, ends up enhanced with festoons of red blossoms, chuckling resoundingly and bare. Seeing a lady who is dark in complexion, who is wicked, who has long hair and nails, hanging breasts, or who is clad in laurels of red blossoms and red articles of clothing is viewed to be as deadly as a fatal night. These are extreme dreams which show demise of a patient ${ }^{(15)}$.

\section{Conclusion}

Swapna (dream) phenomenon \& Swapna related bad prognostic signs are used in ancient times in the diagnosis, prognosis and investigation of disease or to see fatality of diseased or healthy person. Dreadful dreams in a person indicate the decreased mental strength of the person. 'Mind' is component of health and patient can overcome diseases easily with strong mind and will power. Disease is always 
difficult to cure in a depressed person with low will power. This might be a reason why Charak has mentioned importance of dreams while predicting prognosis of any disease. We often give importance to Sharira dosha and neglect or give less importance to Manas dosha in cause and prognosis of disease. Acharya Charak has mentioned seven types of Swapna (dreams) which are 1)Drishta 2)Shruta 3)Anubhuta 4)Prarthita 5)Kalpita 6)Bhavika \& 7)Doshaja out of which only two types of swapna has significant role in the prognosis of disease those are Bhavika \& Doshaja. As first five types of dreams are derived from various external or internal sensory stimuli. Due to imaginary nature and lack of strong will power or desire etc. makes these types of dreams ineffective. Doshaja \& Bhavika types of dreams may be effective due to their strong intensity, having originated from strong wishes and having organic underlying source Due to Doshaja Avastha (Doshadi Prakopa).

Whatever mentioned in dreams as bad prognostic signs as per disease or in general are represent symbolic presentation of that particular disease or internal organic status like Doshadi Prakopa etc. which eventually leads to death of a diseased or healthy person. Hence it plays a significant role in the understanding stage of disease \& helps in treatment. It is very important that this Swapna phenomenon \& its role in prognosis of disease needs further study $\&$ research so that we can include it in as diagnosis \& prognosis part which will ultimately help in treatment.

\section{References:}

1. Dr. Dwivedi Lakshmidhar, Charak Samhita of Maharshi Agnivesha With Ayurvedadipika Sanskrit Commentary by Shri Chakrapanidatta, $4^{\text {th }}$ Edition, Chowkhamba Krishnadas Academy Varanasi, 2017,Varanasi. (Page no. 1178)

2. Dr. Dwivedi Lakshmidhar, Charak Samhita of Maharshi Agnivesha With Ayurvedadipika Sanskrit Commentary by Shri Chakrapanidatta, $4^{\text {th }}$ Edition, Chowkhamba Krishnadas Academy Varanasi, 2017,Varanasi. (Page no. 1213)

3. Dr. Dwivedi Lakshmidhar, Charak Samhita of Maharshi Agnivesha With Ayurvedadipika Sanskrit Commentary by Shri Chakrapanidatta, $4^{\text {th }}$ Edition, Chowkhamba Krishnadas Academy Varanasi, 2017,Varanasi. (Page no. 1213)

4. Dr. Dwivedi Lakshmidhar, Charak Samhita of Maharshi Agnivesha With Ayurvedadipika Sanskrit Commentary by Shri Chakrapanidatta, $4^{\text {th }}$ Edition, Chowkhamba Krishnadas Academy Varanasi, 2017,Varanasi. (Page no. 1214)

5. Dr. Dwivedi Lakshmidhar, Charak Samhita of Maharshi Agnivesha With Ayurvedadipika Sanskrit Commentary by Shri Chakrapanidatta, $4^{\text {th }}$ Edition, Chowkhamba Krishnadas Academy Varanasi, 2017,Varanasi. (Page no. 1214)

6. Dr. Dwivedi Lakshmidhar, Charak Samhita of Maharshi Agnivesha With Ayurvedadipika Sanskrit Commentary by Shri Chakrapanidatta, $4^{\text {th }}$ Edition, Chowkhamba Krishnadas Academy Varanasi, 2017,Varanasi. (Page no. 1215) 
7. Dr. Dwivedi Lakshmidhar, Charak Samhita of Maharshi Agnivesha With Ayurvedadipika Sanskrit Commentary by Shri Chakrapanidatta, $4^{\text {th }}$ Edition, Chowkhamba Krishnadas Academy Varanasi, 2017,Varanasi. (Page no. 1209)

8. Dr. Dwivedi Lakshmidhar, Charak Samhita of Maharshi Agnivesha With Ayurvedadipika Sanskrit Commentary by Shri Chakrapanidatta, $4^{\text {th }}$ Edition, Chowkhamba Krishnadas Academy Varanasi, 2017, Varanasi. (Page no. 1209)

9. Dr. Dwivedi Lakshmidhar, Charak Samhita of Maharshi Agnivesha With Ayurvedadipika Sanskrit Commentary by Shri Chakrapanidatta, $4^{\text {th }}$ Edition, Chowkhamba Krishnadas Academy Varanasi, 2017,Varanasi. (Page no. 1209)

10. Dr. Dwivedi Lakshmidhar, Charak Samhita of Maharshi Agnivesha With Ayurvedadipika Sanskrit Commentary by Shri Chakrapanidatta, $4^{\text {th }}$ Edition, Chowkhamba Krishnadas Academy Varanasi, 2017, Varanasi. (Page no. 1210)

11. Dr. Dwivedi Lakshmidhar, Charak Samhita of Maharshi Agnivesha With Ayurvedadipika Sanskrit Commentary by Shri Chakrapanidatta, $4^{\text {th }}$ Edition,
Chowkhamba Krishnadas Academy Varanasi, 2017,Varanasi. (Page no. 1210)

12. Dr. Dwivedi Lakshmidhar, Charak Samhita of Maharshi Agnivesha With Ayurvedadipika Sanskrit Commentary by Shri Chakrapanidatta, $4^{\text {th }}$ Edition, Chowkhamba Krishnadas Academy Varanasi, 2017,Varanasi. (Page no. 1210)

13. Dr. Dwivedi Lakshmidhar, Charak Samhita of Maharshi Agnivesha With Ayurvedadipika Sanskrit Commentary by Shri Chakrapanidatta, $4^{\text {th }}$ Edition, Chowkhamba Krishnadas Academy Varanasi, 2017,Varanasi. (Page no. 1211)

14. Dr. Dwivedi Lakshmidhar, Charak Samhita of Maharshi Agnivesha With Ayurvedadipika Sanskrit Commentary by Shri Chakrapanidatta, $4^{\text {th }}$ Edition, Chowkhamba Krishnadas Academy Varanasi, 2017,Varanasi. (Page no. 1211)

15. Dr. Dwivedi Lakshmidhar, Charak Samhita of Maharshi Agnivesha With Ayurvedadipika Sanskrit Commentary by Shri Chakrapanidatta, $4^{\text {th }}$ Edition, Chowkhamba Krishnadas Academy Varanasi, 2017,Varanasi. (Page no. 1212). 